\title{
Essential oils of Citrus aurantifolia, Anthemis nobile and Lavandula officinalis: in vitro anthelmintic activities against Haemonchus contortus
}

Luis Eduardo Ferreira', Bruno Iglesias Benincasa', Ana Lúcia Fachin', Silvia Helena Taleb Contini', Suzelei Castro França', Ana Carolina Souza Chagas ${ }^{2}$ and Rene Oliveira Beleboni ${ }^{* *}$

\begin{abstract}
Background: Infections of sheep with gastrointestinal parasites, especially Haemonchus contortus, have caused serious losses in livestock production, particularly after the emergence of resistance to conventional anthelmintics. The search for new anthelmintic agents, especially those of botanical origin, has grown substantially due to the perspective of less contamination of meat and milk, as well as other advantages related to their cost and accessibility in less developed countries. The aim of this study was to evaluate the in vitro anthelmintic activity of essential oils of the plant species Citrus aurantifolia, Anthemis nobile and Lavandula officinalis against the main developmental stages of the parasite $H$. contortus.

Results: Plant species were selected based on substantial ethnopharmacological information. Analysis of the composition of each oil by gas chromatography coupled to mass spectrometry (GC-MS) demonstrated the presence of limonene (56.37\%), isobutyl angelate (29.26\%) and linalool acetate (35.97\%) as the major constituents in C. aurantifolia, A. nobile and L. officinalis, respectively. Different concentrations of each oil were tested in vitro for their capacity to inhibit egg hatching (EHT), larval development (LDT) and adult worm motility (AWMT) using a multidrug-resistant strain of $\mathrm{H}$. contortus (Embrapa 2010). The $I C_{50}$ values obtained for the oils of C. aurantifolia, A. nobile and L. officinalis were $0.694,0.842$ and $0.316 \mathrm{mg} / \mathrm{ml}$ in the EHT and $0.044,0.117$ and $0.280 \mathrm{mg} / \mathrm{ml}$ in the LDT, respectively. The three oils were able to inhibit adult worm motility completely within the first $8-12 \mathrm{~h}$ of observation in the AWMT.

Conclusions: The present results demonstrate significant anthelmintic activity of the three oils against the different developmental stages of $\mathrm{H}$. contortus. Furthermore, this study is of ethnopharmacological importance by validating the anthelmintic activity of the oils studied. Although new experiments are necessary, these data contribute to the development of pharmaceutical-veterinary products for sheep farming by opening up new therapeutic possibilities against gastrointestinal infections caused by $\mathrm{H}$. contortus.
\end{abstract}

Keywords: Botanical anthelmintics, In vitro assays, Plants, Gastrointestinal nematodes, Small ruminants

\footnotetext{
* Correspondence: rbeleboni@unaerp.br; reneusp@yahoo.com

'Unidade de Biotecnologia, Universidade de Ribeirão Preto (UNAERP),

Ribeirão Preto, São Paulo, Brazil

Full list of author information is available at the end of the article
}

(c) The Author(s). 2018 Open Access This article is distributed under the terms of the Creative Commons Attribution 4.0 International License (http://creativecommons.org/licenses/by/4.0/), which permits unrestricted use, distribution, and reproduction in any medium, provided you give appropriate credit to the original author(s) and the source, provide a link to the Creative Commons license, and indicate if changes were made. The Creative Commons Public Domain Dedication waiver (http://creativecommons.org/publicdomain/zero/1.0/) applies to the data made available in this article, unless otherwise stated. 


\section{Background}

There is a great interest in sheep farming because of the high added value of its commercial products [1]. This livestock sector has faced serious problems related to gastrointestinal infections caused mainly by the parasite Haemonchus contortus [2]. The epidemiological importance of this nematode species is related to its wide geographical distribution and pathogenicity. In addition, this parasite is a cause of significant economic losses for the sheep livestock industry around the world [3]. As a result of the inadequate management of infections, resistance against the main classes of commercially available antiparasitic agents (benzimidazoles, macrocyclic lactones and imidazothiazoles) has been developed by this species $[4,5]$, reducing their therapeutic efficacies and consequently increasing associated economic impacts [6].

A technical resource for the prevention and treatment of different veterinary diseases is the use of medicinal plants. Plants have already been used for medical purposes by ancient civilizations and are currently considered a more sustainable and more easily accessible therapeutic and/or preventive alternative to synthetic drugs [7, 8]. These potential advantages have favored the search for new herbal or plant-derived agents for veterinary use, particularly those for the control of gastrointestinal parasites, including $H$. contortus [9].

The choice of the plant species for pharmacological studies is important and should be based on solid operational strategies and relevant ethnopharmacological/ chemotaxonomic data [10]. Within this context, Citrus aurantifolia, Anthemis nobile and Lavandula officinalis were traditionally used in folk medicine as anthelmintics against different etiological agents. They are widely distributed in Brazil, and are relatively good producers of essential oils. The oils extracted from the plants are a rich mixture of terpenes and terpenoids [11]. Many of these compounds have already proven their anthelmintic activities against different parasites, including $H$. contortus. Furthermore, the botanical families and genera to which C. aurantifolia (family Rutaceae; genus Citrus), A. nobile (family Asteraceae; genus Anthemis) and L. officinalis (family Lamiaceae; genus Lavandula) belong are traditionally known for their anthelmintic activity against H. contortus [12-15].

Despite the great potential of $C$. aurantifolia, $A$. nobile and $L$. officinalis as anthelmintics, there are no data on the potential activities of the essential oils of these plants against $H$. contortus. Therefore, the aim of the present study was to investigate the in vitro anthelmintic activity of essential oils obtained from the fruit peel of $C$. aurantifolia (Christm.) Swingle (Rutaceae); flowers of A. nobile (syn. Chamaemelum nobilis (L.) All.) (Asteraceae); and flowers of $L$. officinalis (Chaix \& Kitt.)
(Lamiaceae), against different developmental stages of the parasite $H$. contortus.

\section{Methods \\ Plant material and essential oils}

The essential oils of Citrus aurantifolia, A. nobile and $L$. officinalis were purchased from Kampo de Ervas Ind. \& Com. Ltda-ME (Ribeirão Preto, SP, Brazil), accompanied by the technical datasheets and serial numbers of each species thus: Lot. No. 116, density $(d)=0.868$; Lot. No. 297 , density $(d)=0.908$; Lot. No. 229, density $(d)=0$. 891 , respectively. The essential oils were extracted by hydrodistillation from the fruit peel of $C$. aurantifolia and from the flowers of A. nobile and L. officinalis.

\section{GC-MS analysis}

Samples of each essential oil were analyzed by gas chromatography coupled to mass spectrometry (GC-MS) (Varian, model Saturn 2100T) using the following technical conditions: DB- 5 capillary column $(30 \mathrm{~m} \times 0.25 \mathrm{~mm} \times 0$. $25 \mu \mathrm{m}$ ); gun: $240{ }^{\circ} \mathrm{C}$; detector: $230{ }^{\circ} \mathrm{C}$; electron impact: 70 $\mathrm{eV}$; carrier gas: He; flow rate: $1.0 \mathrm{ml} / \mathrm{min}$; split: 1/20; temperature program: $60-240{ }^{\circ} \mathrm{C}, 3{ }^{\circ} \mathrm{C} / \mathrm{min}$; injection volume: $1 \mu \mathrm{l}$. The chemical compounds were identified by comparison of their mass spectra with the GC-MS database (Nist 62 library) and Kovats retention index [16].

\section{Animals and artificial infection with Haemonchus contortus}

Two male Santa Inês sheep (4-6 months-old, 20-30 kg) were used as feces donors for all experimental protocols. The animals were purchased in the region of Ribeirão Preto (SP, Brazil) and kept at the experimental farm of the University of Ribeirão Preto (UNAERP), receiving ration and hay two times per day and water ad libitum.

For artificial and monospecific infection with $H$. contortus, the animals were first treated with Zolvix ${ }^{\circledR}$ (Monepantel, Novartis Animal Health, $2.5 \mathrm{mg} / \mathrm{kg}$ body weight; Dundee, UK) according to the manufacturer's recommendations. After 14 days, a total reduction in egg load was confirmed by counting the number of eggs per gram of feces (epg =0). The multidrug-resistant $H$. contortus strain, Embrapa 2010, was used for monospecific infection and each animal was inoculated orally with approximately 4000 third-stage (L3) larvae. After 28 days of incubation, infection was confirmed by epg count. Animals with a count of 1500 to 5000 epg were considered parasitologically competent as feces donors for the in vitro assays. According to Chagas et al. [17], strain Embrapa 2010 was isolated from naturally contaminated animals of Embrapa Pecuária Sudeste, São Carlos, SP, and is characterized as resistant to anthelmintics of the benzimidazole, macrocyclic lactone and imidazothiazole classes. 


\section{In vitro anthelmintic assays}

\section{Egg recovery technique}

The egg hatch test (EHT) and larval development test (LDT) described below were carried out after the recovery of $H$. contortus eggs according to the method described previously [18]. Approximately $20 \mathrm{~g}$ of feces were collected from the rectal ampulla of monospecifically infected animals and immediately filtered under running water $\left(37^{\circ} \mathrm{C}\right)$ through sieves with a mesh size of 500,150 , 90 and $20 \mu \mathrm{m}$, respectively. The eggs retained on the last sieve were washed, centrifuged for $5 \mathrm{~min}$ at $1811 \times g$ with distilled water, and recovered in super-saturated saline by simple flotation. After recovery, the eggs were stored on the $20 \mu \mathrm{m}$ sieve for abundant washing with distilled water to produce a final and quantified aqueous solution of eggs.

\section{Egg hatch test (EHT)}

For the EHT, 24-well plates (TPP ref. no. 92024) containing aqueous solutions of approximately 100 eggs/well were used as proposed by Katiki et al. [19]. The treatments consisted of different concentrations of each essential oil (50, $25,12.5,6.25,3.125,1.562,0.781,0.390,0.195$ and 0.097 $\mathrm{mg} / \mathrm{ml}$ ) in a final volume of $0.5 \mathrm{ml} /$ well completed with distilled water. The oils were solubilized in distilled water and Tween $80(3 \%, v / v)$. After incubation for $24 \mathrm{~h}\left(27^{\circ} \mathrm{C}\right)$, the number of eggs and first-stage (L1) larvae were counted under an inverted microscope and compared to the positive (thiabendazole, $0.025 \mathrm{mg} / \mathrm{ml}$ ) and negative controls (3\% Tween $80, \mathrm{v} / \mathrm{v})$. The results were expressed as the mean percentage of inhibition of egg hatching in three independent experiments performed in triplicate.

\section{Larval development test (LDT)}

The LDT was also carried out in 24-well plates containing approximately 100 eggs/well. Following the method described previously [20], $80 \mu \mathrm{l}$ of nutritive medium (Escherichia coli, yeast extract, amphotericin B) was added to each well and completed with distilled water to a final volume of $250 \mu \mathrm{l}$. After incubation for $24 \mathrm{~h}\left(27^{\circ}\right.$ C), different concentrations of each essential oil (3.0, 1.5, $0.75,0.375,0.187,0.0937,0.0468,0.0234,0.0117,0.0058$ and $0.0029 \mathrm{mg} / \mathrm{ml}$ ) were solubilized in distilled water and DMSO $(1 \%, \mathrm{v} / \mathrm{v})$ and added to each well, resulting in a final volume of $0.5 \mathrm{ml}$. After 6 days, the differential count of L1, L2 and L3 larvae was performed and compared to the data obtained for the positive (levamisole, $20 \mathrm{mg} / \mathrm{ml}$ ) and negative controls (1\% DMSO, v/v). The results are the average of three replicates and are expressed as the percentage of larval development inhibition of three independent experiments.

\section{Adult worm motility test (AWMT)}

The AWMT was performed after necropsy for removal of the abomasum and recovery of adult parasites from sheep infected artificially with the resistant isolate Embrapa 2010, using the method described previously [21]. In 24-well plates, five adult parasites/well were treated separately with each essential oil at final concentrations of $50,5.0$ and $0.5 \mathrm{mg} / \mathrm{ml}$. The oils were solubilized in PBS + antibiotic solution (penicillin/ streptomycin) $(4 \%)+$ Tween $80(2 \%)$ in a final volume of $1 \mathrm{ml} /$ well. The plates were kept in an oven at a controlled temperature $\left(37^{\circ} \mathrm{C}\right)$ throughout the experiment and mobile and immobile adult parasites were counted at intervals of $2 \mathrm{~h}$. The total time of the experiment was defined when extensive parasite death was observed in the negative control $(24 \mathrm{~h})$. In fact, the effect of essential oils on the adult worm motility was estimated considering the natural nematode motility inhibition in the negative controls. Levamisole $(20 \mathrm{mg} / \mathrm{ml})$ was used as positive control and the negative controls consisted of PBS + antibiotic solution (penicillin/streptomycin) (4\%) + Tween 80 (2\%) and PBS + antibiotic solution (penicillin/streptomycin) (4\%). The results are the average of three replicates and are expressed as the percentage of motility of adult parasites when exposed to different concentrations of essential oils of three independent experiments.

\section{Statistics}

One-way ANOVA followed by Tukey's test $(P<0.05)$ was used for statistical analysis. Nonlinear regression/ logarithmic distributions were applied to calculate the minimum concentration that inhibited $50 \%\left(\mathrm{IC}_{50}\right)$ of egg hatching or larval development.

\section{Results}

\section{GC-MS results}

Analysis by GC-MS identified 91.17\%, 90.54\% and 91. 99\% of the present chemical constituents in oils of $C$. aurantifolia, A. nobile and L. officinalis, respectively. A wide variety of compounds were found in each oil; however, the major constituents were limonene (56.37\%), $\beta$ pinene $(11.86 \%)$ and $\gamma$-terpinene $(11.42 \%)$ in $C$. aurantifolia oil; isobutyl angelate (29.26\%), isoamyl angelate (15. $27 \%)$ and $\alpha$-thujene (8.92\%) in A. nobile oil, and linalool acetate $(35.97 \%)$, trans-sabinene hydrate $(29.17 \%)$ and camphor (5.54\%) in L. officinalis oil (Table 1).

\section{In vitro anthelmintic activity}

The EHT results for the three essential oils showed an inhibitory effect on egg hatching higher than $85-90 \%$ for a concentration range of 3.125 to $50 \mathrm{mg} / \mathrm{ml}$ : L. officinalis (ANOVA: $\left.F_{(11,24)}=1394, P<0.0001\right) ; A$. nobile (ANOVA: $\left.F_{(11,24)}=571.2, P<0.0001\right) ; C$. aurantifolia (ANOVA: $\left.F_{(11,24)}=703.6, P<0.0001\right)$ The $\mathrm{IC}_{50}$ values were $0.316 \mathrm{mg} / \mathrm{ml}$ for $L$. officinalis, $0.694 \mathrm{mg} / \mathrm{ml}$ for $C$. aurantifolia, and $0.842 \mathrm{mg} / \mathrm{ml}$ for $A$. nobile. These 
Table 1 Relative percentage (\%) of compounds from essential oils determined by CG-MS

\begin{tabular}{|c|c|c|c|c|}
\hline $\mathrm{Rl}$ & Component & C. aurantifolia & A. nobilis & L. officinalis \\
\hline 914 & Amyl acetate & - & 0.10 & - \\
\hline 1062 & Artemisia ketona & - & 5.84 & - \\
\hline 1505 & $\beta$-Bisabolene & 0.89 & - & - \\
\hline 1169 & Borneol & - & 0.18 & 2.14 \\
\hline 811 & Butyl acetate & - & 1.11 & 0.80 \\
\hline 954 & Camphene & - & 0.52 & 0.18 \\
\hline 1146 & Camphor & - & - & 5.54 \\
\hline 1419 & (E)-Caryophyllene & - & - & 2.37 \\
\hline 1031 & 1.8-Cineole & - & 3.97 & 4.87 \\
\hline 952 & Cyclohexanone $<3$-methyl-> & - & 0.62 & - \\
\hline 1024 & $\rho$-Cymene & 4.17 & - & - \\
\hline 804 & Ethyl butanoate & - & 0.41 & 4.08 \\
\hline 990 & Furfuryl acetate & - & 0.61 & - \\
\hline 1101 & Hexyl propanoate & - & 0.25 & - \\
\hline 1146 & Isoamyl angelate & - & 15.27 & - \\
\hline 1009 & Isoamyl isobutyrate & - & 2.73 & - \\
\hline 1160 & Isoborneol & - & - & 0.30 \\
\hline 1051 & Isobutyl angelate & - & 29.26 & - \\
\hline 911 & Isobutyl isobutyrate & - & 3.93 & - \\
\hline 1090 & Isobutyl tiglate & - & 0.71 & - \\
\hline 876 & Isopentyl acetate & - & - & 0.42 \\
\hline 1290 & Lavandulyl acetate & - & - & 0.77 \\
\hline 1029 & Limonene & 56.37 & - & 0.52 \\
\hline 1257 & Linalool acetate & - & - & 35.97 \\
\hline 1088 & -Mentha-2,4(8)-diene & - & - & 0.24 \\
\hline 988 & Myrcene & 0.67 & - & 0.16 \\
\hline 1195 & Myrtenol & - & 0.77 & - \\
\hline 1050 & (E)- $\beta$-Ocimene & - & - & 0.74 \\
\hline 1037 & (Z)- $\beta$-Ocimene & - & - & 0.56 \\
\hline 1132 & Allo-Ocimene & - & - & 0.61 \\
\hline 991 & 3-Octanol & - & 0.56 & - \\
\hline 1055 & Pentyl isobutanoate & - & 0.53 & - \\
\hline 979 & $\beta$-Pinene & 11.86 & - & - \\
\hline 1170 & Pinocampheol & - & - & 0.31 \\
\hline 1175 & Cis-Pinocamphone & - & 0.37 & - \\
\hline 1164 & Pinocarvone & - & 3.15 & - \\
\hline 975 & Sabinene & - & 6.27 & 0.22 \\
\hline 1098 & Trans-Sabinene hydrate & - & - & 29.17 \\
\hline 1221 & Cis-Sabinene hydrate acetate & - & - & 0.14 \\
\hline 1142 & Trans-Sabinol & - & 4.47 & - \\
\hline 1177 & 4-ol-Terpinen & - & - & 0.74 \\
\hline 1059 & $\gamma$-Terpinene & 11.42 & - & - \\
\hline 1199 & y-Terpineol & - & - & 0.85 \\
\hline 930 & a-Thujene & 2.85 & 8.92 & 0.31 \\
\hline
\end{tabular}


Table 1 Relative percentage (\%) of compounds from essential oils determined by CG-MS (Continued)

\begin{tabular}{lllll}
\hline Rl & Component & C. aurantifolia & A. nobilis & - \\
1431 & Cis-Thujopsene & 1.20 & - & - \\
& Verbenene & 1.74 & $9 f f i c i n a l i s$ \\
& Not identifield & 8.83 & 9.46 & - \\
& Total analyzed & 91.17 & 90.54 & 91.99 \\
\hline
\end{tabular}

Abbreviation: $\mathrm{Rl}$, retention index

results are shown in Table 2. The inhibitory effect on egg hatching exhibited a dose-dependent response profile for all oils studied.

As observed in the EHT, the anthelmintic activity of all tested oils was also promising in the LDT. The rate of inhibition of larval development by the essential oil of C. aurantifolia was greater than $85 \%$ at a concentration of $0.187 \mathrm{mg} / \mathrm{ml}$ (ANOVA: $F_{(11,24)}=$ 2540, $P<0.0001)$ or higher, with this oil showing the lowest $\mathrm{IC}_{50}(0.044 \mathrm{mg} / \mathrm{ml})$ among the oils tested. For the oil of $A$. nobile, the $\mathrm{IC}_{50}$ was $0.117 \mathrm{mg} / \mathrm{ml}$, achieving an inhibition greater than $85 \%$ at a concentration of $0.375 \mathrm{mg} / \mathrm{ml}$ (ANOVA: $F_{(11,24)}=1309, P<$ 0.0001). The results obtained for the L. officinalis oil showed inhibition greater than $85 \%$ only for concentrations above $1.5 \mathrm{mg} / \mathrm{ml}$ (ANOVA: $F_{(11,24)}=1485, P$ $<0.0001)$ and the $\mathrm{IC}_{50}$ value was the highest among the oils tested $(0.280 \mathrm{mg} / \mathrm{ml})$ (Table 3). The inhibitory effect of the oils on larval development was dose dependent.

In the AWMT, all essential oils induced faster paralysis of adult parasites than the negative controls [PBS $+4 \%$ antibiotic (penicillin-streptomycin) $+2 \%$ Tween 80 ; PBS $+4 \%$ antibiotic (penicillin-streptomycin)], completely inhibiting motility within the first $8-12 \mathrm{~h}$ of observation. In addition, a marked overall inhibition of motility of $50 \%$ or higher was observed for all oils within the first $2-4 \mathrm{~h}$ of the experiment (Table 4). The profile of anthelmintic activity of the oils was similar to that observed for the positive control, even when levamisole was used in a very high concentration $(20 \mathrm{mg} / \mathrm{ml})$ (Table 4$)$.

\section{Discussion}

The use of in vitro assays in veterinary parasitology, especially a series of tests for the evaluation of action against the main stages of a parasite (eggs, larvae and adults), is advantageous for the choice of substances to be tested in vivo [22]. These assays are rapid, inexpensive and simple. They reduce the number of animals that are necessary for in vivo testing, and permit the combined and optimized assessment of a series of compounds for both the development of new drugs and the study of resistance to different anthelmintics. Within this context, different approaches have used this experimental strategy for the study of anthelmintic agents, including those against $H$. contortus [23].

Table 2 Effects (mean percentage \pm SE) of tested essential oils on inhibition of egg hatching of $H$. contortus

\begin{tabular}{llll}
\hline Concentration $(\mathrm{mg} / \mathrm{ml})$ & C. aurantifolia & A. nobilis & L. officinalis \\
\hline 50 & $100.0 \pm 0.0^{\mathrm{a}, \mathrm{b}}$ & $99.0 \pm 0.38^{\mathrm{a}, \mathrm{b}}$ & $100.0 \pm 0.0^{\mathrm{a}, \mathrm{b}}$ \\
25 & $100.0 \pm 0.0^{\mathrm{a}, \mathrm{b}}$ & $99.4 \pm 0.87^{\mathrm{a}, \mathrm{b}}$ & $100.0 \pm 0.0^{\mathrm{a}, \mathrm{b}}$ \\
12.5 & $98.9 \pm 1.87^{\mathrm{a}, \mathrm{b}}$ & $97.0 \pm 2.38^{\mathrm{a}, \mathrm{b}}$ & $99.8 \pm 0.30^{\mathrm{a}, \mathrm{b}}$ \\
6.25 & $96.4 \pm 2.61^{\mathrm{a}, \mathrm{b}}$ & $95.7 \pm 2.13^{\mathrm{a}, \mathrm{b}}$ & $99.4 \pm 0.94^{\mathrm{a}, \mathrm{b}}$ \\
3.125 & $95.9 \pm 2.41^{\mathrm{a}, \mathrm{b}}$ & $86.4 \pm 4.71^{\mathrm{b}}$ & $92.3 \pm 3.03^{\mathrm{b}}$ \\
1.562 & $86.9 \pm 2.33^{\mathrm{b}}$ & $74.5 \pm 3.58^{\mathrm{b}}$ & $82.8 \pm 3.62^{\mathrm{b}}$ \\
0.781 & $56.2 \pm 3.97^{\mathrm{b}}$ & $63.3 \pm 4.12^{\mathrm{b}}$ & $85.0 \pm 3.15^{\mathrm{b}}$ \\
0.390 & $42.1 \pm 4.70^{\mathrm{b}}$ & $26.6 \pm 1.46^{\mathrm{b}}$ & $81.8 \pm 1.36^{\mathrm{b}}$ \\
0.195 & $14.9 \pm 3.89^{\mathrm{b}}$ & $13.4 \pm 2.33^{\mathrm{b}}$ & $9.5 \pm 1.54^{\mathrm{b}}$ \\
0.097 & $13.0 \pm 1.44^{\mathrm{b}}$ & $14.1 \pm 2.60^{\mathrm{b}}$ & $6.8 \pm 1.69$ \\
& $C_{50}=0.694 \mathrm{mg} / \mathrm{ml}$ & $1 C_{50}=0.842 \mathrm{mg} / \mathrm{ml}$ & $1 C_{50}=0.316 \mathrm{mg} / \mathrm{ml}$ \\
& $R^{2}=0.985$ & $R^{2}=0.978$ & $R^{2}=0.950$ \\
Thiabendazol $(0.025 \mathrm{mg} / \mathrm{ml})$ & $100.0 \pm 0.0^{\mathrm{b}}$ & $100.0 \pm 0.0^{\mathrm{b}}$ & $100.0 \pm 0.0^{\mathrm{b}}$ \\
\hline Tween $80(3 \%)$ & $7.6 \pm 0.85$ & $7.4 \pm 3.94$ & $3.5 \pm 0.82$ \\
\hline
\end{tabular}

Abbreviations: $\mathrm{IC}_{50}$, inhibitory concentration $50 \% ; R^{2}$, nonlinear correlation coefficient

${ }^{a}$ No statistically significant difference between positive control and treatments

${ }^{\mathrm{b}}$ Significant difference between positive control or treatments with negative control (ANOVA, followed by Tukey test; $P<0.05$ ) 
Table 3 Effects (mean percentage \pm SE) of different concentrations of essential oils on inhibition of larval development of $H$. contortus

\begin{tabular}{|c|c|c|c|}
\hline Concentration (mg/ml) & C. aurantifolia & A. nobilis & L. officinalis \\
\hline 3.0 & - & $100.0 \pm 0.0^{a, b}$ & $95.3 \pm 1.84^{\mathrm{a}, \mathrm{b}}$ \\
\hline 1.5 & $100.0 \pm 0.0^{\mathrm{a}, \mathrm{b}}$ & $100.0 \pm 0.0^{\mathrm{a}, \mathrm{b}}$ & $89.8 \pm 0.88^{b}$ \\
\hline 0.75 & $100.0 \pm 0.0^{a, b}$ & $97.2 \pm 2.26^{a, b}$ & $81.4 \pm 1.83^{b}$ \\
\hline 0.375 & $90.1 \pm 1.68^{b}$ & $86.4 \pm 2.34^{b}$ & $64.2 \pm 1.79^{b}$ \\
\hline 0.187 & $85.4 \pm 2.62^{b}$ & $67.1 \pm 3.26^{b}$ & $35.9 \pm 0.98^{b}$ \\
\hline 0.0937 & $71.5 \pm 1.35^{b}$ & $46.9 \pm 1.18^{b}$ & $11.5 \pm 0.95$ \\
\hline 0.0468 & $61.8 \pm 1.16^{\mathrm{b}}$ & $31.3 \pm 2.81^{b}$ & $12.0 \pm 2.83$ \\
\hline 0.0234 & $41.2 \pm 0.81^{b}$ & $27.4 \pm 1.61^{b}$ & $9.9 \pm 2.02$ \\
\hline 0.0117 & $14.7 \pm 1.81^{b}$ & $20.5 \pm 1.28^{b}$ & $8.8 \pm 1.44$ \\
\hline 0.0058 & $10.8 \pm 0.35$ & $12.4 \pm 1.17$ & $6.3 \pm 0.64$ \\
\hline \multirow[t]{3}{*}{0.0029} & $9.1 \pm 0.59$ & - & - \\
\hline & $I C_{50}=0.044 \mathrm{mg} / \mathrm{ml}$ & $\mid C_{50}=0.117 \mathrm{mg} / \mathrm{ml}$ & $\mathrm{IC}_{50}=0.280 \mathrm{mg} / \mathrm{ml}$ \\
\hline & $R^{2}=0.983$ & $R^{2}=0.989$ & $R^{2}=0.994$ \\
\hline Levamisol (20 mg/ml) & $99.8 \pm 0.21^{b}$ & $99.8 \pm 0.21^{b}$ & $99.8 \pm 0.21^{b}$ \\
\hline DMSO (1\%) & $9.3 \pm 2.16$ & $7.8 \pm 0.72$ & $7.5 \pm 3.17$ \\
\hline
\end{tabular}

Abbreviations: $C_{50}$, inhibitory concentration $50 \% ; R^{2}$, nonlinear correlation

${ }^{a}$ No statistically significant difference between positive control and treatments

${ }^{\mathrm{b}}$ Significant difference between positive control or treatments with negative control (ANOVA, followed by Tukey test; $P<0.05$ )

For the development of new anthelmintic agents, it is important that the parasite species, and even its strain, be the most representative of the livestock in reality, especially when this type of economical activity faces different challenges [4]. Haemonchus contortus strain, Embrapa 2010, is known to be resistant to the main classes of commercially available anthelmintic drugs, such as benzimidazoles, macrocyclic lactones and imidazothiazoles [17]. In fact, this anthelmintic resistance profile is very similar to that found on sheep farms throughout Brazil, particularly in the State of São Paulo [24].

Essential oils consist of a mixture of volatile and lipophilic compounds with a strong and characteristic odor. Terpenes and terpenoids are their main chemical constituents. These compounds differ by the presence of an oxygen atom in terpenoids and a methyl radical in terpenes [25]. In view of the low solubility of essential oils in water, a tensoactive solution or solvent was used to increase the solubilization of these substances in the

Table 4 Percentage of motility of $\mathrm{H}$. contortus adult worns when exposed to different concentrations of essential oils

\begin{tabular}{|c|c|c|c|c|c|c|c|c|c|c|c|c|c|c|}
\hline & \multirow[b]{2}{*}{ Concentration $(\mathrm{mg} / \mathrm{ml})$} & \multicolumn{13}{|c|}{ Time (hours) } \\
\hline & & 0 & 2 & 4 & 6 & 8 & 10 & 12 & 14 & 16 & 18 & 20 & 22 & 24 \\
\hline Control (+) & - & 100 & $49^{b}$ & $22^{b}$ & $9^{b}$ & $2^{b}$ & $0^{b}$ & $0^{\mathrm{b}}$ & $0^{b}$ & $0^{\mathrm{b}}$ & $0^{\mathrm{b}}$ & $0^{b}$ & $0^{\mathrm{b}}$ & 0 \\
\hline Control (-) 1 & - & $100^{\mathrm{a}}$ & 100 & 91 & 84 & 71 & 53 & 40 & 31 & 22 & 16 & 11 & 7 & $0^{\mathrm{a}}$ \\
\hline Control (-) 2 & - & $100^{a}$ & 100 & 91 & 80 & 64 & 51 & 33 & 24 & 18 & 13 & 4 & 2 & $0^{a}$ \\
\hline \multirow[t]{3}{*}{ C. aurantifolia } & 50.0 & $100^{\mathrm{a}}$ & $49^{a, b}$ & $27^{a, b}$ & $11^{a, b}$ & $7^{a, b}$ & $0^{a, b}$ & $0^{a, b}$ & $0^{a, b}$ & $0^{a, b}$ & $0^{a, b}$ & $0^{a, b}$ & $0^{a, b}$ & $0^{a}$ \\
\hline & 5.0 & $100^{\mathrm{a}}$ & $49^{a, b}$ & $27^{a, b}$ & $18^{a, b}$ & $9^{a, b}$ & $0^{a, b}$ & $0^{a, b}$ & $0^{a, b}$ & $0^{a, b}$ & $0^{a, b}$ & $0^{a, b}$ & $0^{a, b}$ & $0^{a}$ \\
\hline & 0.5 & $100^{\mathrm{a}}$ & $87^{b}$ & $58^{b}$ & $40^{b}$ & $13^{b}$ & $9^{b}$ & $0^{a, b}$ & $0^{a, b}$ & $0^{a, b}$ & $0^{a, b}$ & $0^{a, b}$ & $0^{a, b}$ & $0^{a}$ \\
\hline \multirow[t]{3}{*}{ A. nobilis } & 50.0 & $100^{a}$ & $44^{a, b}$ & $13^{\mathrm{a}, \mathrm{b}}$ & $4^{a, b}$ & $0^{a, b}$ & $0^{a, b}$ & $0^{a, b}$ & $0^{a, b}$ & $0^{a, b}$ & $0^{a, b}$ & $0^{a, b}$ & $0^{a, b}$ & $0^{a}$ \\
\hline & 5.0 & $100^{a}$ & $49^{a, b}$ & $18^{a, b}$ & $13^{a, b}$ & $0^{a, b}$ & $0^{a, b}$ & $0^{a, b}$ & $0^{a, b}$ & $0^{a, b}$ & $0^{a, b}$ & $0^{a, b}$ & $0^{a, b}$ & $0^{a}$ \\
\hline & 0.5 & $100^{a}$ & $69^{b}$ & $38^{b}$ & $33^{b}$ & $16^{\mathrm{b}}$ & $0^{a, b}$ & $0^{a, b}$ & $0^{a, b}$ & $0^{a, b}$ & $0^{a, b}$ & $0^{a, b}$ & $0^{a, b}$ & $0^{a}$ \\
\hline \multirow[t]{3}{*}{ L. officinalis } & 50.0 & $100^{\mathrm{a}}$ & $44^{a, b}$ & $31^{a, b}$ & $13^{a, b}$ & $7^{a, b}$ & $0^{a, b}$ & $0^{\mathrm{a}}$ & $0^{a, b}$ & $0^{a, b}$ & $0^{a, b}$ & $0^{a, b}$ & $0^{a, b}$ & $0^{a}$ \\
\hline & 5.0 & $100^{a}$ & $56^{a, b}$ & $36^{b}$ & $29^{b}$ & $1^{a, b}$ & $2^{a, b}$ & $0^{a}$ & $0^{a, b}$ & $0^{a, b}$ & $0^{a, b}$ & $0^{a, b}$ & $0^{a, b}$ & $0^{a}$ \\
\hline & 0.5 & $100^{\mathrm{a}}$ & $82^{b}$ & $54^{\mathrm{b}}$ & $44^{\mathrm{b}}$ & $24^{b}$ & $13^{\mathrm{b}}$ & $9^{a, b}$ & $0^{a, b}$ & $0^{\mathrm{a}, \mathrm{b}}$ & $0^{a, b}$ & $0^{a, b}$ & $0^{a, b}$ & $0^{a}$ \\
\hline
\end{tabular}

Key: Control (+), levamisole 20 mg/ml; Control (-) 1, PBS + antibiotic (penicillin/streptomycin) 4\% + tween 80 2\%; Control (-) 2, PBS + antibiotic (penicillin/streptomycin) $4 \%$

${ }^{\text {a }}$ No statistically significant difference between positive control and treatments

${ }^{\mathrm{b}}$ Significant difference between positive control or treatments with negative control (ANOVA, followed by Tukey test; $P<0.05$ ) 
present experiments. Tween 80 at $3 \%(\mathrm{v} / \mathrm{v})$ and at $2 \%(\mathrm{v} /$ v) was used in the EHT and AWMT, respectively, while $1 \%$ DMSO (v/v) was used in the LDT because L1 larvae are more sensitive to Tween 80 than to DMSO [19]. The negative and positive controls used in the different tests yielded the expected results, demonstrating appropriate standardization of the experimental protocol and, consequently, the reliability of the findings obtained (Tables 1, 2 and 3).

Human knowledge of essential oils originated in the pre-Christian era [10]. Anthelmintic properties, including against $H$. contortus, have been described for a large number of essential oils such as those of Croton zehntneri [26], Eucalyptus staigeriana [27], Cymbopogon martinii and Mentha piperita [28], Lippia sidoides [29] and Thymus vulgaris [30].

In the present study, the essential oil of $L$. officinalis was more effective in the EHT than the oils of $C$. aurantifolia and especially of $A$. nobile. In fact, the $\mathrm{IC}_{50}$ value of the L. officinalis oil was about 2.0-2.5 times lower than that of the other two oils tested (Table 2). In the LDT, the oil of $C$. aurantifolia exhibited the best performance, with an $\mathrm{IC}_{50}$ value that was about 2.5 and 6.5 times lower than those obtained for the oils of $A$. nobile and $L$. officinalis, respectively, and was therefore the most potent against larval development (Table 3). The variations in anthelmintic performance between the different tests and oils might be explained by qualitative and quantitative differences in the composition of the essential oils studied (Table 1) and different sensitivity to the various developmental stages of $H$. contortus. However, similar results were obtained in the AWMT for the oils tested, which did not permit a clear distinction of their pharmacological efficacy for this assay (Table 4). Furthermore, regardless of the variations in absolute $\mathrm{IC}_{50}$ values, all oils acted effectively and in a dosedependent manner against the three developmental stages of $H$. contortus, which is a relevant finding.

Regarding the chemical compounds shown in Table 1, some of the volatile compounds identified are major constituents or are common in the different plant species studied. For example, limonene was identified as a major constituent in the oil of C. aurantifolia (56.37\%). Limonene is characteristic of species of the genus Citrus [31]. However, although at low concentrations, limonene was also found in the oil of L. officinalis $(0.52 \%)$ (Table 1 ). Myrcene was identified at low concentration in the oils of C. aurantifolia and $L$. officinalis (Table 1). Borneol, butyl acetate, camphene, 1,8-cineol and sabinene, also at low concentrations, can be found in both the oils of $A$. nobilis and of L. officinalis (Table 1). Except for $\alpha$-thujene, which occurs in the oils of C. aurantifolia, A. nobilis and L. officinalis at proportions of $2.85 \%, 8.82 \%$ and $0.31 \%$, respectively, no other compound identified occurred simultaneously in the three types of oils studied (Table 1), a finding supporting the chemical diversity of the oils. In fact, the essential oils studied here are composed of a wide diversity of compounds that represent a vast repertoire of active biomolecules of biotechnological interest. This permits the theoretical establishment of a natural product library for structure-activity correlation studies that are important for current pharmacology [32].

Linalool acetate and trans-sabinene hydrate are the major constituents of plants of the family Lamiaceae, especially in the genus Lavandula [33]. These were also the two main compounds identified in the oil of $L$. officinalis $(35.97 \%$ and $29.17 \%$, respectively) (Table 1 ). In addition to limonene (see above), other compounds present in the oil of $C$. aurantifolia should be mentioned, including $\gamma$-terpinene and $\beta$-pinene at proportions of $11.42 \%$ and $11.86 \%$, respectively (Table 1 ). Two major constituents are present in the oil of A. nobilis, isobutyl angelate (29.26\%) and isoamyl angelate (15.27\%) (Table 1). These compounds, which are major constituents of all three oils studied, might be the main substances responsible for the different anthelmintic activities observed in this study. However, we cannot rule out that different compounds act synergistically to establish the final pharmacological effect in each case, or that compounds present in small or trace amounts are involved in the anthelmintic effect observed. In the latter case, $\alpha$-thujene was not a major constituent in any of the oils studied, but was found in all three of them, although at variable low proportions (Table 1). This compound may represent a common functional link between the three different oils, all of them exhibiting anthelmintic activity.

In addition to the representative importance of major constituents of each oil studied, some of these compounds possess known anthelmintic properties, highlighting their potential importance in final anthelmintic activity. The evidence for the activity of such compounds can be direct or indirect, as observed for $H$. contortus. For example, limonene is found in the oils of different plants with anthelmintic activity, such as Lippia sidoides, Cymbopogon martinii, Mentha piperita and Eucalyptus staigeriana [19, 29, 34]. This compound accounts for $96.0 \%$ of the composition of the essential oil of Citrus sinensis, causing $100 \%$ inhibition of $H$. contortus eggs and larvae in vitro at most concentrations tested [35]. Linalool acetate is known for its anthelmintic activity against Ascaris lumbricoides [4]. Although not a major constituent of any of the oils, 1,8-cineole was present in both the oil of $A$. nobilis and L. officinalis. This compound is well known to be effective against the egg and larval stage of $H$. contortus [13].

In view of the economic impacts of gastrointestinal infections on sheep farming, which are increasingly 
aggravated by anthelmintic resistance, the identification and development of new therapeutic options for prevention, control or eradication of this problem is essential $[10,36]$. In this respect, there has been intensified search for botanical anthelmintics against $H$. contortus because of the advantages of these agents, such as low cost and easy access, especially in less developed countries with biodiversity [37]. Since botanical anthelmintics may contain different compounds that act synergistically and throughout the life-cycle of the parasite, they may be less susceptible to pharmacological resistance, although this suggestion is controversial [22]. Finally, additional advantages are that botanical anthelmintics are generally well tolerated by animals from a toxicological point of view and appear to leave fewer residues in animal products such as meat and milk [37].

The application of ethnopharmacological/chemotaxonomic-based strategies is important to optimize studies of botanical anthelmintic agents in order to increase the success of developing new plant-derived or herbal agents of interest for the pharmaceutical-veterinary industry [10]. Although in vivo studies are still needed, the present work preliminarily validates the ethnopharmacological and chemotaxonomic data that indicate the use of C. aurantifolia, A. nobile and L. officinalis as anthelmintics. This is the first study testing the essential oils of these plants against $H$. contortus, highlighting their ethnopharmacological use and pharmaceutical-veterinary value.

\section{Conclusions}

This study reveals the in vitro effects of $C$. aurantifolia, $A$. nobile and $L$. officinais essential oils against the main developmental stages of the parasite $H$. contortus. It highlights the importance of promising medicinal plants and theirs chemical compounds for the development of new potential anthelmintic agents.

\section{Abbreviations}

AWMI: Adul worm motility test; DMSO: Dimethyl sulfoxide; EHT: Egg hatch test; EPG: Eggs per gram of feces; GC-MS: Gas chromatography coupled to mass spectrometry; LDT: Larval development test; PBS: Phosphate-buffered solution

\section{Acknowledgements}

We thank Fapesp, CNPq and Capes agencies for their financial support and EMBRAPA (Brazilian Agricultural Research Corporation)/UNAERP for technical and scientific support.

\section{Funding}

This study was supported by FAPESP (Foundation of São Paulo State Research - Project No. 2012/17405-4), CNPq (Proc. 304592/2013-7), CAPES and University of Ribeirão Preto.

\section{Availability of data and materials}

Original data used and analyzed during the current study are available from the corresponding author upon reasonable request.

\section{Authors' contributions}

LEF, BBI, SHTC performed the laboratorial work and manuscript was written and edited by the other authors. The principal investigator for this study is
ROB. Those responsible for the examination of the whole manuscript were ROB, SCF, ACSC and ALF. All authors read and approved the final manuscript.

\section{Ethics approval}

All experimental procedures involving the use of animals were approved by the Ethics Committee of UNAERP (Protocol No. 042/2012) and were conducted in accordance to current legislation and guidelines for the use of experimental animals.

\section{Competing interests}

The authors declare that they have no competing interests.

\section{Publisher's Note}

Springer Nature remains neutral with regard to jurisdictional claims in published maps and institutional affiliations.

\section{Author details}

${ }^{1}$ Unidade de Biotecnologia, Universidade de Ribeirão Preto (UNAERP), Ribeirão Preto, São Paulo, Brazil. ²Embrapa Pecuária Sudeste (CPPSE), São Carlos, São Paulo, Brazil.

Received: 7 October 2017 Accepted: 16 April 2018

Published online: 25 April 2018

\section{References}

1. Cruz DG, Rocha LO, Arruda SS, Palieraqui JGB, Cordeiro RC, Junior ES, et al. Anthelmintic efficacy and management practices in sheep farms from the state of Rio de Janeiro, Brazil. Vet Parasitol. 2010;170:340-3.

2. Chintoan-Uta C, Morgan ER, Skuce PJ, Coles GC. Wild deer as potential vectors of anthelmintic-resistant abomasal nematodes between cattle and sheep farms. Proc Biol Soc. 2014;281:1-9.

3. Hurtado FA, Guzmán MAM. Immune responses associated with resistance to haemonchosis in sheep. Biomed Res Int. 2013;2013:162158.

4. Kaplan RM, Vidyashankar AN. An inconvenient truth: global worming and anthelmintic resistance. Vet Parasitol. 2012;186:70-8.

5. Lespine A, Ménez C, Bourguinat C, Prichard RK. P-glycoproteins and other multidrug resistance transporters in the pharmacology of anthelmintics: prospects for reversing transport-dependent anthelmintic resistance. Int J Parasitol Drugs Drug Resist. 2012;2:58-75.

6. Roeber F, Jex AR, Gasser RB. Advances in the diagnosis of key gastrointestinal nematode infections of livestock, with an emphasis on small ruminants. Biotechnol Adv. 2013;31:1135-52

7. Petrovska BB. Historical review of medicinal plants usage. Pharmacogn Rev. 2012;6:1-5

8. Ndob IB, Mengome LE, Bourobou HPB, Banfora YL, Bivigou F. Ethnobotanical survey of medicinal plants used as anthelmintic remedies in Gabon. J Ethnopharmacol. 2016;191:360-71.

9. Gregory L, Yoshihara E, Ribeiro BL, Silva LK, Marques EC, Meira EB Jr, et al. Dried, ground banana plant leaves (Musa spp.) for the control of Haemonchus contortus and Trichostrongylus colubriformis infections in sheep. Parasitol Res. 2015;114:4545-51.

10. McChesney JD, Venkataraman SK, Henri JT. Plant natural products: back to the future or into extinction? Phytochemistry. 2007;68:2015-22.

11. Echeverrigaray S, Zacaria J, Beltrão R. Nematicidal activity of monoterpenoids against the root-knot nematode Meloidogyne incognita. Phytopathology. 2010;100:199-203.

12. Eguale T, Tadesse D, Giday M. In vitro anthelmintic activity of crude extracts of five medicinal plants against egg-hatching and larval development of Haemonchus contortus. J Ethnopharmacol. 2011;137:108-13.

13. Zhu L, Dai JL, Yang L, Qiu L. In vitro anthelmintic activity of Zanthoxylum simulans essential oil against Haemonchus contortus. Vet Parasitol. 2013;211:223-7.

14. Irum S, Ahmed H, Mukhtar M, Mushtaq M, Mirza B, Donskow-Lysoniewska K, et al. Anthelmintic activity of Artemisia vestita Wall ex DC. and Artemisia maritima L. against Haemonchus contortus from sheep. Vet Parasitol. 2015: 212:451-5.

15. Qi H, Wang WX, Dai JL, Zhu L. In vitro anthelmintic activity of Zanthoxylum simulans essential oil against Haemonchus contortus. Vet Parasitol. 2015;211:223-7.

16. Adams RP. Identification of essential oil components by gas chromatography/ mass spectroscopy. Carol Stream: Allured Publishing Co.; 1995. 
17. Chagas ACS, Katiki LM, Silva IC, Giglioti R, Esteves SN, Oliveira MCS, et al. Haemonchus contortus: a multiple-resistant Brazilian isolate and the costs for its characterization and maintenance for research use. Parasitol Int. 2013;62:1-6.

18. Coles GC, Bauer C, Borgsteede FH, Geerts S, Klei TR, Taylor MA, et al. World Association for the Advancement of Veterinary Parasitology (W.A.A.V.P.) methods for the detection of anthelmintic resistance in nematodes of veterinary importance. Vet Parasitol. 1992;44:35-44.

19. Katiki LM, Chagas ACS, Bizzo HR, Ferreira JFS, Amarante AFT. Anthelmintic activity of Cymbopogon martinii, Cymbopogon schoenanthus and Mentha piperita essential oils evaluated in four different in vitro tests. Vet Parasitol. 2011:183:103-8.

20. Hubert J, Kerboeuf D. A microlarval development assay for the detection of anthelmintic resistance in sheep nematodes. Vet Rec. 1992;130:442-6.

21. Hounzangbe-Adote M, Paolini V, Fouraste I, Moutairou K, Hoste H. In vitro effects of four tropical plants on three life-cycle stages of the parasitic nematode, Haemonchus contortus. Res Vet Sci. 2005;78:155-60.

22. Demeler J, Gill JH, Himmelstjerna GVS, Sangster NC. The in vitro assay profile of macrocyclic lactone resistance in three species of sheep trichostrongyloids. Int J Parasitol Drugs Drug Resist. 2013;3:109-18.

23. Sangster NC, Gill J. Pharmacology of anthelmintic resistance. Parasitol Today. 1999;15:141-6.

24. Veríssimo CJ, Niciura SC, Alberto AL, Rodrigues CF, Barbosa CM, Chiebao DP, et al. Multidrug and multispecies resistance in sheep flocks from São Paulo state, Brazil. Vet Parasitol. 2012;187:209-16.

25. Cho KS, Lim YR, Lee K, Lee J, Lee JH, Lee IS. Terpenes from forests and human health. Toxicol Res. 2017:33:97-106.

26. Camurça-Vasconcelos ALF, Bevilaqua CML, Morais SM, Maciel MV, Costa CTC, Macedo ITF, et al. Anthelmintic activity of Croton zehntneri and Lippia sidoides essential oils. Vet Parasitol. 2007;148:288-94.

27. Macedo ITF, Bevilaqua CML, Oliveira LMB, Camurça-Vasconcelos ALF, Vieira LS, Oliveira FR, et al. Anthelmintic effect of Eucalyptus staigeriana essential oil against goat gastrointestinal nematodes. Vet Parasitol. 2010;173:93-8.

28. Katiki LM, Chagas ACS, Takahira RK, Juliani HR, Ferreira JFS, Amarante AFT. Evaluation of Cymbopogon schoenanthus essential oil in lambs experimentally infected with Haemonchus contortus. Vet Parasitol. 2012; 186:312-8.

29. Carvalho CO, Chagas ACS, Cotinguiba F, Furlan M, Brito LG, Chaves FCM, et al. The anthelmintic effect of plant extracts on Haemonchus contortus and Strongyloides venezuelensis. Vet Parasitol. 2012;183:260-8.

30. Ferreira LE, Benincasa BI, Fachin AL, França SC, Contini SHT, Chagas ACS, et al. Thymus vulgaris $L$. essential oil and its main component thymol: anthelmintic effects against Haemonchus contortus from sheep. Vet Parasitol. 2015;228:70-6.

31. Bourgou S, Rahali FZ, Ourghemmi I, Saidani Tounsi M. Changes of peel essential oil composition of four Tunisian citrus during fruit maturation. Sci Worl J. 2012;2012:528593.

32. Staniek A, Bouwmeester H, Fraser PD, Kayser O, Martens S, Tissier A, et al. Natural products - modifying metabolite pathways in plants. Biotechnol J. 2013:8:1159-71.

33. Zheljazkov VD, Cantrell CL, Astatkie T, Jeliazkova E. Distillation time effect on lavender essential oil yield and composition. J Oleo Sci. 2013;62:195-9.

34. Ribeiro WLC, Macedo ITF, Santos JML, Oliveira EF, Camurça-Vasconcelos ALF, Paula HCB, et al. Activity of chitosan-encapsulated Eucalyptus staigeriana essential oil on Haemonchus contortus. Exp Parasitol. 2013;135:24-9.

35. Gaínza YA, Domingues LF, Perez OP, Rabelo MD, López ER, Chagas ACS. Anthelmintic activity in vitro of Citrus sinensis and Melaleuca quinquenervia essential oil from Cuba on Haemonchus contortus. Ind Crops Prod. 2015;76:647-52.

36. Wink M. Medicinal plants: A source of anti-parasitic secondary metabolites. Molecules. 2012;17:12771-91.

37. Ferreira LE, Castro PMN, Chagas ACS, França SC, Beleboni RO. In vitro anthelmintic activity of aqueous leaf extract of Annona muricata $\mathrm{L}$. (Annonaceae) against Haemonchus contortus from sheep. Exp Parasitol. 2013;134:327-32.

\section{Ready to submit your research? Choose BMC and benefit from:}

- fast, convenient online submission

- thorough peer review by experienced researchers in your field

- rapid publication on acceptance

- support for research data, including large and complex data types

- gold Open Access which fosters wider collaboration and increased citations

- maximum visibility for your research: over $100 \mathrm{M}$ website views per year

At BMC, research is always in progress.

Learn more biomedcentral.com/submissions 